Jurnal Ekonomi \& Studi Pembangunan

Volume 19, Nomor 1, April 2018, hlm. 11-20

DOI: 10.18196/jesp.19.1.4111

\title{
EFISIENSI TEKNIS BADAN USAHA MILIK DAERAH (BUMD) BIDANG JASA PRODUKSI PROVINSI JAWA TENGAH
}

\author{
Maskun Suwardi dan P. Eko Prasetyo \\ Fakultas Ekonomi, Universitas Negeri Semarang, Indonesia, Phone +62248508015 \\ E-mail Korespondensi: kunsuwardi08@gmail.com
}

\begin{abstract}
This research was aimed to analyze the level of technical efficiency and identify some factors that influence it and also solutions necessary to conduct to improve the efficiency of BUMD of production service field in Central Java Province. The analysis method used a Data Envelopment Analysis (DEA) by a frontier analysis approach. The BUMN analysis unit of production service field was in Central Java. Variables used were input variables (capital deposited, total expenses and employee numbers) and output variables (income, profit before tax and dividend realization). Data used was a secondary data of BUMD of production service field periods 2011-2016. The research objects covered PD. CMJT, PT. SPJT, PT. SPHC, PDAB TU and PT. PRPP. The research results showed that out of five BUMDs of production service field in Central Java Province, there were two inefficient BUMDs include PDAB TU and PT. PRPP. PDAB TU was not efficient in 2012, 2013 and 2016, while PT. PRPP was not efficient during 2011-2016. Three out of five BUMDs namely PD. CMJT, PT. SPJT and PT. SPHC achieved efficiency of $100 \%$ during research period. The BUMDs inefficiency occurred due to combining unsuitable input variable magnitude so that needed to conduct adjustment of input factor magnitude in yielding output efficiently $100 \%$. It could be concluded that there is a trend of efficiency in BUMD of production service field every year and there are two inefficient BUMDs. The BUMD inefficiency was caused by combining disproportional input factor magnitude. It was suggested the two inefficient BUMDs should adjust input factor value magnitude in achieving output efficiently $100 \%$
\end{abstract}

Key Words: efficiency, DEA, BUMD, production service

JEL Classification: L52, C52, D23, D24

\section{PENDAHULUAN}

Menurut Undang-Undang No.23 Tahun 2014, BUMD adalah badan usaha yang sebagian besar atau seluruh modalnya dimiliki oleh pemerintah daerah. Melalui BUMD, pemerintah daerah dapat memaksimalkan peran dalam hal pembangunan ekonomi daerah. Dasar hukum munculnya BUMD adalah Undang-Undang No. 5 Tahun 1962 tentang Perusahaan Daerah dan Undang-Undang No. 5 Tahun 1974, tentang pokokpokok Pemerintah di Daerah. Undang-Undang No. 23 tahun 2014, pasal 331 ayat empat, menjelaskan tujuan dari pendirian badan usaha milik daerah antara lain; (1) Memberikan manfaat perkembangan ekonomi untuk daerah (2) menyelenggarakan kemanfaatan umum, berupa penyediaan barang dan/atau jasa yang bermutu untuk memenuhi kebutuhan hajat hidup masyarakat sesuai karakteristik, potensi daerah dengan tata kelola penyelenggaraan perusahaan yang baik (3) memperoleh laba dan/atau keuntungan. Secara umum, BUMD di Indonesia dibedakan berdasarkan kategori bidang usaha. Terdapat 15 kategori bidang usaha, mulai dari usaha pertanian, penggalian tambang, hiburan, penyedia jasa ilmiah, keuangan dan jasa hiburan, rekreasi. Data BPS Tahun 2014 menunjukan ada 777 BUMD di Indonesia, yang terdiri atas 115 perusahaan milik Pemerintah Provinsi dan 662 perusahaan milik 
Pemerintah Kabupaten/Kota. Data perkembangan jumlah BUMD berdasarkan kepemilikan saham tahun 2011-2014 di Indonesia sebagai berikut.

Tabel 1. Jumlah BUMD Menurut Kepemilikan Saham Tahun 2011-2014

\begin{tabular}{lcccc}
\hline Pemilikan Saham & 2011 & 2012 & 2013 & 2014 \\
\hline Provinsi & 100 & 106 & 116 & 115 \\
\hline Kabupaten / Kota & 623 & 602 & 631 & 662 \\
\hline Jumlah & 723 & 708 & 747 & 777 \\
\hline
\end{tabular}

Sumber: BPS, Statistik Keuangan 2014

Berdasarkan besaran aset, equitas dan laba pada tahun 2014, BUMD di Indonesia membukukan laba sebesar Rp9,8 triliun, asset sebesar Rp662 triliun dan equitas sebesar Rp206 triliun. Bidang usaha keuangan memperoleh tingkat laba tertinggi dengan capaian Rp7,9 triliun atau 81\% mendominasi total laba BUMD pada tahun 2014. Secara umum, tingkat aset dan equitas bidang usaha keuangan masih yang tertinggi, yakni dengan total kepemilikan aset Rp605 triliun atau 91\% kontribusi pada total aset BUMD serta tingkat equitas sebesar Rp175 triliun. BUMD di kategori real estate memiliki total aset, ekuitas, dan laba bersih. Pemerintah Provinsi Jawa Tengah tercatat memiliki delapan BUMD. Terdiri dari BUMD bidang Keuangan (PD.BPR BKK, PD BKK, PT.Bank Jateng, PT. Jamkrida Jateng), dan BUMD bidang Jasa Produksi (PD.CMJT, PDAB Tirta Utama, PT.PRPP, PT.SPJT, PT.SPHC). Dasar hukum pendirian BUMD Provinsi Jawa Tengah diatur dalam Peraturan Daerah dan Peraturan Gubernur. Kepemilikan modal Pemerintah provinsi pada setiap BUMD berada pada kisaran 45\%-100\% dengan penyertoran modal berkala pada setiap tahunnya. Menurut Akbar (2012), kinerja merupakaan salah satu indikator efisiensi suatu perusahaan. Kinerja efisiensi BUMD menjadi sebuah ukuran hasil yang dijadikan salah satu pedoman pemerintah daerah dalam menilai tingkat keberhasilan sebuah BUMD.

Hasil kinerja BUMD, layaknya sebuah perusahaan yang semuanya merupakan hasil perpaduan berbagai faktor kerja perusahaan, baik secara internal maupun eksternal yang saling mempengaruhi. Menurut Ghiselli \& Brown dalam Setio Budi (2010), istilah efisiensi dimaknai, menunjukkan adanya perbandingan antara keluaran (output) dengan masukan (input). Kemampuan menghasilkan output secara maksimal dengan input yang ada, menjadi salah satu hasil kinerja yang baik. Urgensinya adalah bahwa Efisiensi merupakan ukuran yang menunjukkan bagaimana sebaiknya sumber-sumber daya ekonomi dialokasikan dalam proses produksi untuk menghasilkan output maksimal. Menurut AlDelaimi dan Al-Ani (2006), efisiensi dalam hal ini efisiensi teknis, memiliki arti bahwa adanya kegiatan pemindahan input yang berbentuk fisik seperti tenaga kerja dan modal menjadi hasil (output) pada tingkat kinerja terbaik, ketika tidak terdapat input yang terbuang dalam kegiatan produksi sejumlah output. Pada efisiensi BUMD dapat diartikan bahwa ketika BUMD dapat menghasilkan sebuah output yang maksimal dengan input yang dimiliki, maka BUMD dapat dinyatakan memiliki nilai efisiensi yang baik (Deskriptif BUMD dan PID Provinsi Jawa Tengah 2016).

Berdasarkan tabel-2 dilihat dari asset, pendapatan dan deviden, BUMD bidang keuangan masih mendominasi kontribusi terhadap total BUMD di Jawa Tengah yakni antara 45\%-98\%. Sementara BUMD bidang Jasa produksi hanya memberikan kontribusi terhadap total asset, pendapatan dan deviden pada kisaran 3\%-4,5\%. Hal ini tentu menjadi permasalahan serius bagi 
pengelolaan BUMD di Jawa Tengah, mengingat bahwa andil BUMD bidang jasa produksi dalam kontribusinya terhadap PAD juga masih relatif kecil. Keberadaan BUMD bidang Jasa Produksi diharapkan terus memiliki andil besar pada perekonomian Jawa Tengah. Sesuai dengan komitmen pemerintah Provinsi Jawa Tengah melalui modal yang telah disetorkan.

Berdasarkan tabel-2, perbandingan total asset BUMD Bidang Keuangan dengan BUMD Bidang Jasa Produksi terlampau sangat tinggi (perbandingan 37:1) Untuk tingkat pendapatan antara bidang keuangan dan jasa produksi memiliki (perbandingan 30:1). Fenomena ini, sejalan dengan kontribusi masing-masing BUMD terhadap PAD melalui besaran deviden yang diberikan. Sumbangan deviden BUMD bidang Jasa produksi dari tahun 2014-2016 tidak lebih dari 5\% dari total deviden BUMD Provinsi Jawa Tengah. Pentingnya dilakukan riset ini adalah bahwa ketimpangan hasil kinerja pada BUMD bidang keuangan dan bidang jasa produksi tentunya tidak bisa dibiarkan bigitu saja, sehingga modal pemerintah yang telah disetorkan tetap mendapatkan pengembalian keuntungan yang sesuai. Dibutuhkan analisis yang mendasar mengenai permasalahan yang terjadi pada BUMD bidang Jasa Produksi, sehingga mampu meningkatkan kontribusi BUMD dan bersaing dengan BUMD bidang keuangan dan BUMS. Walaupun secara bisnis BUMD memiliki karakteristik yang berbeda dengan BUMS. BUMD bidang Jasa Produksi memliki peranan yang sama penting dengan BUMD bidang Keuangan.

BUMD bidang usaha jasa produksi meliputi; usaha dagang, penggalian, edukasi dan rekreasi memiliki cakupan yang cukup luas untuk memenuhi permintaan pasar dan turut andil membangun perekonomian di Jawa Tengah. Kondisi kinerja keuangan yang masih relatif kecil menjadikan BUMD bidang Jasa Produksi yang cenderung tidak profitable. (Analisis Kinerja BUMD Jawa Tengah, Deskriptif BUMD Jawa Tengah, 2014). Salah satunya dapat dilihat melalui return of investment yang rata-rata hanya berkisar antara $18 \%-45 \%$, sementara ROI BUMD bidang keuangan mencapai 97\%-170\% (Data Deskriptif PID, BUMD 2016). Adapun Kinerja keuangan BUMD bidang Jasa Produksi dapat di lihat pada Tabel 2.

Tabel 2. BUMD Bidang Keuangan, dan Jasa Produksi Tahun 2014-2016 (Juta Rupiah)

\begin{tabular}{clrrr}
\hline Bidang & \multicolumn{1}{c}{ Keterangan } & Des 2014 & \multicolumn{1}{c}{ Des 2015 } & \multicolumn{1}{c}{ Juni 2016 } \\
\cline { 2 - 5 } Keuangan & Asset & 43.163 .323 & 50.051 .654 & 59.604 .447 \\
\cline { 2 - 5 } & Pendapatan & 7.739 .555 & 8.044 .616 & 3.516 .881 \\
\cline { 2 - 5 } & Deviden & 262.990 & 293.786 & 307.316 \\
\hline Bidang & Asset & 1.388 .123 & 1.729 .337 & 1.657 .322 \\
\cline { 2 - 5 } Jasa Produksi & Pendapatan & 1.388 .123 & 484.116 & 117.964 \\
\cline { 2 - 5 } & Deviden & 23.013 & 19.523 & 24.386 \\
\hline
\end{tabular}

Sumber: Data Deskriptif BUMD Biro Perekonomian Setda Provinsi Jawa Tengah tahun 2011-2016

Sebagai sebuah badan usaha, maka BUMD tentunya melakukan proses produksi sebagai salah satu aktifitas utamanya. Produksi adalah segala kegiatan yang bertujuan untuk meningkatkan atau menambah guna atas suatu benda, atau segala kegiatan yang ditujukan untuk memuaskan orang lain melalui pertukaran. Dalam teori ekonomi, efisiensi dalam produksi merupakan syarat penting untuk meningkatkan produktivitas dan daya saing usaha. Melihat urgensi keberadaan BUMD bidang Jasa Produksi Provinsi Jawa Tengah dalam membangun perekonomian daerah, maka perlu adanya analisis mendalam menganai tingkat efisiensi pada masing-masing BUMD. Dalam artikel ini akan dianalisis tingkat efisiensi pada BUMD bidang jasa produksi yang 
didasarkan pada pendekatan efisiensi relatif secara teknis dan mengidentifikasi beberapa faktor yang mempengaruhi serta solusinya. Pengertian prinsip efisiensi yang dimaksud dalam artikel ini cederung lebih mengacu kepada UU no. 23 tahun 2014. Prinsip efisiensi dalam ketentuan UU no. 23 tahun 2014 ini adalah penyelenggara suatu urusan Pemerintahan ditentukan berdasarkan perbandingan tingkat daya guna yang paling tinggi yang dapat diperoleh. Sedangkan, asas efisiensi adalah asas yang berorientasi pada minimalisasi penggunaan sumber daya dalam penyelenggaraan negara untuk mencapai hasil kerja yang terbaik.

\section{METODE PENELITIAN}

Berdasarkan jenis data yang diperoleh, penelitian ini merupakan jenis penelitian kuantitatif. Jenis data yang digunakan pada penelitian ini adalah data sekunder. Data yang digunakan dalam penelitian ini berupa data keuangan umum BUMD bidang jasa produksi Provinsi Jawa Tengah yang didapat langsung melalui dokumentasi pengumpulan data pada Biro Perekonomian Sekretariat Daerah Provinsi Jawa Tengah, bagian Pengembangan Investasi Daerah dan BUMD. Metode pengumpulan data yang digunakan adalah studi pustaka. Subjek penelitian ini adalah Badan Usaha Milik Daerah (BUMD) bidang jasa produksi Provinsi Jawa Tengah. Pada saat ini terdapat lima perusahaan daerah yang termasuk dalam BUMD bidang jasa produksi. Adapun lima perusahaan daerah tersebut adalah; PD.CMJT, PT.SPJT, PT.SPHC, PT.PRPP dan PD.ABTU. Identifikasi variabel input-output yang digunakan dalam pengukuran tingkat efisiensi merupakan langkah pertama dan terpenting (Purwantoro, dalam Prasetyo, 2010). Adapun variabel input dan output yang digunakan dalam penelitian ini adalah:

a. Jumlah Tenaga Kerja $\left(\mathrm{I}_{1}\right)$

b. Modal disetor Pemerintah $\left(I_{2}\right)$ c. Biaya Total BUMD $\left(\mathrm{I}_{3}\right)$

d. Pendapatan $\left(\mathrm{O}_{1}\right)$

e. Laba Sebelum Pajak $\left(\mathrm{O}_{2}\right)$

f. Realisasi Deviden $\left(\mathrm{O}_{3}\right)$

Pengukuran tingkat efisiensi BUMD bidang jasa produksi pada penelitian ini digunakan alat bantu analsisi Data Envelopment Analysis (DEA) dengan acuan dasar variabel input dan output, yang dianalisis dengan bantuan aplikasi Banxia Frontier Analysis (BFA). Metode DEA adalah metode nonparametrik yang berbasis pada programasi linier. DEA mengukur rasio efisiensi relatif Unit Kegiatan Ekonomi (UKE) sebagai rasio output tertimbang dengan input tertimbang. Secara konsep, DEA menjelaskan tentang langkah yang dirancang untuk mengukur efisiensi relatif suatu unit ekonomi tertentu dengan beberapa unit ekonomi yang lain dalam satu pengamatan, dan digunakan jenis input dan output yang sama. Penerapan metode DEA diasumsikan sudah relevan dan respresentatif untuk menganalisis pokok masalah efisiensi BUMD yang dimaksud dalam riset ini. Dalam model DEA menunjukkan unit ekonomi yang memiliki efisiensi sempurna dengan nilai 100\% dan yang kurang efisien atau tidak efisien dengan nilai $<100 \%$. Di samping itu, terdapat angka multiplier yang digunakan sebagai dasar perbaikan manajerial.

Formulasi digunakan model DEA dalam riset ini, misalnya dilakukan perbandingan efisiensi dari sejumlah UKE, pada penelitian ini UKE adalah asset BUMD yang mengahasilkan; pendapatan, laba dan realisasi deviden. Setiap UKE menghasilkan $m$ jenis input untuk menghasilkan s jenis output. Misalnya $\mathrm{Xij}_{\mathrm{j}}>0$ merupakan jumlah input $\mathrm{i}$ yang digunakan oleh UKE j, dan misalnya Yij > 0 merupakan jumlah output $r$ yang dihasilkan oleh UKE $j$.

$$
Z_{k}=\frac{\sum_{r}^{s}=1 U_{r k} Y_{r k}}{\sum_{i}^{m}=1 V_{i k} X_{i k}}
$$


$Z_{k}=$ Efisiensi Teknis BUMD bidang jasa produksi yang dimaksud.

Kriteria universalitas mensyaratkan unit kegiatan ekonomi k untuk memiliki bobot dengan batasan atau kendala bahwa tidak ada satu unit kegiatan ekonomi lain yang akan memiliki efisiensi lebih besar 1 atau 100 persen, jika unit kegiatan ekonomi lain tersebut digunakan bobot yang dipilih oleh unit kegiatan ekonomi $\mathrm{k}$ sehingga formulasi sebagai berikut:

$$
\frac{\sum_{r}^{s}=1 U_{r k} Y_{r k}}{\sum_{i}^{m}=1 V_{i k} X_{i k}} \leq i, i=1 \ldots \ldots, n
$$

Urk $\geq 0 ; \mathrm{r}=1, \ldots \ldots \ldots \ldots . \mathrm{s}$

Vik $\geq 0 ; r=1, \ldots \ldots \ldots \ldots \ldots m$

Di mana n, merupakan jumlah populasi dari objek penelitian ini yang berjumlah lima perusahaan daerah yang masuk dalam BUMD bidang jasa produksi. Pertidaksamaan pertama meunjukkan adanya efisiensi untuk UKE lain tidak lebih dari 1, sementara persamaan kedua berbobot positif. Angka rasio akan bervariasi antara 0 sampai dengan 1. Objek penelitian dinyatakan efisien jika memiliki angka rasio mencapai 100 persen, sebaliknya jika mendekati 0 menunjukan tingkat efisiensi objek yang semakin rendah.

Ada beberapa bagian program linear yang dapat ditransformasikan ke dalam program ordinary linear untuk menurunkan model DEA dalam riset ini digunakan pendekatan CRS (Constan Return $t i$ Scale) sebagai berikut. Misalnya pendekatan CRS ini digunakan untuk mengukur tingkat efisiensi teknis pada BUMD yang menjadi sampel, diantaranya dengan memaksimumkan sampel.

Adapun fungsi kendala atau batasan sebagai berikut.

$$
\begin{gathered}
Z_{k}=\sum_{r}^{s}=1 U_{r k} Y_{r k} \\
\sum_{r}^{s}=1 U_{r k} Y_{r k}-\sum_{i}^{m}=1 V_{i k} X_{i k} \leq 0 ; \mathrm{j}=1, \ldots, \mathrm{N} \\
U_{r k} \geq 0 ; \mathrm{r}=1, \ldots \ldots \ldots \ldots . \mathrm{s} \\
V_{i k} \geq 0 ; \mathrm{r}=1, \ldots \ldots \ldots \mathrm{m}
\end{gathered}
$$

Di mana:

Yrk = Jumlah output pendapatan, laba sebelum pajak dan realisasi deviden yang dihasilkan oleh UKE.

Xik = Jumlah input modal, biaya dan jumlah tenaga kerja yang dibutuhkan UKE.

$\mathrm{S} \quad=$ Jumlah UKE yang dianalisis

$\mathrm{M}$ = Jumlah input yang digunakan

VIK = Bobot tertimbang dari output (pendapatan, laba sebelum pajak, realisasi deviden)

Zik = Nilai dari maksimisasi sebagai indikator tingkat efisiensi sample penelitian.

Skala efisiensi tiap UKE dapat diperoleh dari perhitungan CRS dan VRS (Varian Retirn to Scale). Misalnya pada UKE, perhitungan skala efisiensinya dihitung dari nilai efisiensi teknis model CRS dibagi dengan nilai efisiensi teknis model VRS. Jika terdapat perbedaan nilai efisiensi teknis model CRS dan VRS dari sebuah UKE, maka hal ini mengindikasikan adanya skala yang tidak efisien. Sebuah UKE yang efisien berada dalam model VRS mengindikasikan mencapai efisiensi teknis secara murni. Apabila UKE berada dalam model CRS, maka telah mencapai efisiensi teknis dan lebih efisien dalam skala operasinya, rumusnya adalah sebagai berikut:

$\mathrm{E}=\mathrm{CRS} / \mathrm{VRS}$

$\mathrm{SE} \quad=$ skala efisiensi

CRS = nilai efisiensi teknis model CRS

VRS = nilai efisiensi teknis model VRS

Di mana $0 \leq \mathrm{SE} \leq 1, \mathrm{CRS} \leq \mathrm{VRS}$, nilai $\mathrm{SE}$ adalah satu yang dapat mengindikasikan UKE beroperasi pada CRS. Nilai SE $<1$ mengindikasikan adanya skala operasi yang tidak efisien. Jika nilai NI (Non Increasing) lebih kecil dari VRS (NI < VRS), maka UKE beroperasi pada IRS (Increasing Returns to Scale), dan jika nilai NI sama dengan VRS (NI = VRS) maka UKE beroperasi pasa DRS (Decreasing Return to Scale). Nilai NI merupakan perluasan dari rumor DEA di mana nilai Urk, Vik menjadi kurang dari 1. 


\section{HASIL DAN PEMBAHASAN}

Efisiensi Badan Usaha Milik Daerah (BUMD) bidang jasa produksi, merupakan salah satu indikator dalam mengukur capaian kinerja BUMD bidang jasa produksi yang dimiliki oleh pemerintah Provinsi Jawa Tengah. Kinerja
BUMD bidang jasa produksi dinyatakan efisien apabila angka rasio efisiensi faktor input dan output sama dengan 1 atau (100\%), sementara jika nilai efisiensi mendekati 0 dan atau kurang dari 1 (E <1 atau $\mathrm{E}<100 \%)$, maka dapat diartikan BUMD bidang jasa produksi tersebut tidak efisien.

Tabel 3. Hasil Riset Efisiensi Teknis BUMD bidang Jasa Produksi 2011-2016

\begin{tabular}{lcccccc}
\hline \multicolumn{1}{c}{ BUMD } & \multicolumn{7}{c}{ Tingkat Efisiensi } \\
\hline & 2011 & 2012 & 2013 & 2014 & 2015 & 2016 \\
PD. CMJT & 1 & 1 & 1 & 1 & 1 & 1 \\
PT. SPJT & 1 & 1 & 1 & 1 & 1 & 1 \\
PT. SPHC & - & - & 1 & 1 & 1 & 1 \\
PD. ABTU & 1 & 0,9178 & 0,7391 & 1 & 1 & 0,5209 \\
PT. PRPP & 0,6884 & 0,6871 & 0,8483 & 0,6921 & 0,3319 & 0,4794 \\
\hline
\end{tabular}

Sumber: Hasil Penelitian, 2017

Berdasarkan hasil peneltian pada tabel 3, terdapat 5 BUMD bidang jasa produksi yang diamati pada periode riset tahun 2011-2016. Pada table 3, ada tiga BUMD bidang jasa produksi yang selalu mencapai efisiensi teknis sama dengan 1 atau 100\%, dan ada dua BUMD yang belum efisien. BUMD yang sudah efisiensi tersebut diantaranya; PD.CMJT, PT.SPJ, dan PT.SPHC. Sedangkan, dua BUMD yang mengalami inefisiensi atau belum mampu mencapai efisiensi 100\% adalah PD.ABTU dan PT.PRPP. PD ABTU mengalami inefisiensi pada tahun 2012, 2013 dan 2016. Nilai efisiensi PD.ABTU terus menurun atau semakin tidak efisien yakni; mulai tahun 2012 sebesar 0,9178, tahun $2013(0,7391)$ dan tahun 2016 (0,5209). BUMD ke dua yang mengalami inefisiensi adalah PT.PRPP. Inefisiensi PT.PRPP mulai terjadi selama periode riset yakni sejak dari tahun 2011-2016. Hasil riset ini sejalan dengan riset sebelumnya yang dilakukan oleh Indrawati (2009) dengan digunakan periode data 2006-2008, hasil riset tersebut menunjukkan bahwa BUMD bidang jasa produksi di daerah Kabupaten Karanganyar sebagai bagian dari Propinsi Jawa Tengah juga tidak efisien.
Hasil riset dalam penelitian ini selama periode 2011-2016, menunjukkan hasil yang terusmenerus mengalami inefisiensi yang semakin buruk, dengan nilai capaian tingkat efisiensi terendah sebesar 0,3319 arau kurang dari 0,50 yang berarti dapat dinyatakan sangat tidak efisien dalam menjalankan usahanya. Fenomena semakin tidak efisiennya BUMD bidang jasa produksi PT.PRPP ini jika terus dibiarkan jelas akan sangat merugikan masyarakat daerah di Jawa Tengah khususnya warga masyarakat Kota Semarang. Karena fungsi PT.PRPP yang bidang usahanya sebagai penyedia jasa wisata edukasi, rekreasi dan pengiklanan tidak dapat dimanfaatkan secara maksimal oleh warga masyarakat. Oleh karena itu, untuk BUMD bidang produksi jasa yang belum mencapai efisiensi teknis 100\% khususnya PD.ABTU dan PT. PRPP disarankan untuk terusmenerus melakukan penyesuain kombinasi besaran nilai alokasi faktor input dalam rangka menghasilkan faktor input secara efisien. Ada beberapa cara yang harus dilakukan yakni; mengoptimalkan ouput atau dengan cara meminimkan alokasi penggunaan input. 
Sesuai dengan tabel 4, secara umum dapat dinyatakan bahwa tingkat efisiensi BUMD bidang jasa produksi di Propinsi Jawa Tengah adalah cukup baik, di mana selama periode riset 20112016 secara rerata ada sebesar 67,50\% (3 dari 5) BUMD yang efisien dan ada sebesar 32,50\% (2 dari 5) BUMD yang tidak efisien pada periode yang sama. Sedangkan, tingkat rata-rata efisiensi dari lima BUMD secara umum masih lebih baik yakni sebesar $88,50 \%$ selama periode penelitian 2011-2016.

Tabel 4. Tingakt Rata-Rata Efisiensi BUMD Bidang Jasa Produksi Secara Umum

\begin{tabular}{|c|c|c|c|c|c|c|}
\hline Keterangan & 2011 & 2012 & 2013 & 2014 & 2015 & 2016 \\
\hline $\begin{array}{l}\text { Jumlah BUMD } \\
\text { yang Efisien }\end{array}$ & 3 & 2 & 3 & 4 & 4 & 3 \\
\hline $\begin{array}{l}\text { Jumlah BUMD } \\
\text { yang tidak } \\
\text { Efisien }\end{array}$ & 1 & 2 & 2 & 1 & 1 & 2 \\
\hline $\begin{array}{l}\text { \% BUMD yang } \\
\text { Efisien }\end{array}$ & $75 \%$ & $50 \%$ & $60 \%$ & $80 \%$ & $80 \%$ & $60 \%$ \\
\hline $\begin{array}{l}\text { \% BUMD yang } \\
\text { tidak Efisien }\end{array}$ & $25 \%$ & $50 \%$ & $40 \%$ & $20 \%$ & $20 \%$ & $40 \%$ \\
\hline BUMD Efisien & $\begin{array}{l}\text { PD.CMJT } \\
\text { PT.SPJT } \\
\text { PD.ABTU }\end{array}$ & $\begin{array}{l}\text { PD.CMJT } \\
\text { PT.SPJT }\end{array}$ & $\begin{array}{l}\text { PD.CMJT } \\
\text { PT.SPJT } \\
\text { PT.SPHC }\end{array}$ & $\begin{array}{l}\text { PD.CMJT } \\
\text { PT.SPJT } \\
\text { PT.SPHC } \\
\text { PD.ABTU }\end{array}$ & $\begin{array}{l}\text { PD.CMJT } \\
\text { PT.SPJT } \\
\text { PT.SPHC } \\
\text { PD.ABTU }\end{array}$ & $\begin{array}{c}\text { PD.CMJT } \\
\text { PT.SPJT } \\
\text { PT.SPHC }\end{array}$ \\
\hline $\begin{array}{l}\text { BUMD Tidak } \\
\text { Efisien }\end{array}$ & PT.PRPP & $\begin{array}{l}\text { PT.PRPP } \\
\text { PD.ABTU }\end{array}$ & $\begin{array}{l}\text { PT.PRPP } \\
\text { PD.ABTU }\end{array}$ & PT.PRPP & PT.PRPP & $\begin{array}{l}\text { PT.PRPP } \\
\text { PD.ABTU }\end{array}$ \\
\hline Rata - rata & $92 \%$ & $90 \%$ & $91 \%$ & $93 \%$ & $86 \%$ & $79 \%$ \\
\hline
\end{tabular}

Sumber: Hasil Penelitian, 2017

Berdasarkan tabel-4, tingkat efisiensi BUMD bidang jasa produksi pemerintah Provinsi Jawa Tengah tertinggi dapat dicapai pada tahun 2014. Pada tahun 2014 ada 80\% BUMD yang efisien dan $20 \%$ BUMD saja yang tidak efisien, serta secara rerata tingkat efisiensi BUMD dapat mencapai sebesar 93\%. Dengan kata lain, pada tahun 2014 ada empat BUMD yang efisien dan hanya satu jenis BUMD saja yang tidak efisien yakni PT.PRPP. Sementara itu, tingkat inefisiensi tertinggi terjadi pada tahun 2012, yakni tingkat inefisiensi mencapai 50\%. Fenomena yang menarik dan perlu diperhatikan selama periode riset 2011-2016 dan khususnya pada periode 20142016 adalah adanya kecederungan BUMD di Propinsi Jawa Tengah yang semakin tidak efisien.

Berdasarkan metode analisis dengan teknik DEA, maka bagi BUMD yang belum efisien harus melakukan penyesuaian dalam alokasi penggunaan input faktor produksi. Dalam penelitian ini untuk BUMD yang tidak efisien disarankan bahwa pelaku industri harus mengurangi biaya produksi yang dinilai mengganggu untuk meningkatkan capaian kinerja. Hasil riset menegaskan bahwa beberapa BUMD bidang jasa produksi harus mengurangi besaran total biaya BUMD, agar mampu mencapai kombinasi input yang proporsional dan meningkatkan nilai efisiensi BUMD. Perlunya dilakukan kombinasi teknis input secara proporsional pada BUMD bidang jasa produksi, sejalan dengan teori ekonomi produksi yang digambarkan melalui kurva isoquant atau kurva isoproduct. Dasar teori ekonomi produski tersebut menjelaskan bahwa kurva isoquant menunjukan berbagai kemungkinan kombinasi teknis antara dua input (varia- 
bel) yang terbuka bagi produsen untuk yang berjudu "Pengukuran Efisiensi BUMD, menghasilkan tingkat output tertentu.

Penyesuaian faktor input lain diantaranya adalah faktor input tenaga kerja. Hasil riset ini menunjukkan bahwa ada beberapa BUMD bidang jasa produksi yang mengalami inefisiensi, salah satu diantaranya adalah adanya penggunaan kombinasi besaran jumlah tenaga kerja sebagai faktor input yang kurang tepat. Hasil riset ini mendukung riset yang dilakukan oleh Akbar dan Isa (2012), dalam penelitiannya

Studi Empirik: PDAM eks Karesidenan Surakarta", menjelaskan bahwa penentuan jumlah kombinasi tenaga kerja memberi dampak pada capaian tingkat efisiensi PDAM di eks Karesidenan Surakarta. Hal ini sejalan dengan teori the law of diminishing return.

Sebagai salah satu contoh solusi mengatasi inefisiensi BUMD PT.PRPP di tahun 2016 dapat dilihat hasilnya seperti pada tabel-5.

Tabel 5. Inefisiensi BUMD pada PT.PRPP Tahun 2016

\begin{tabular}{|c|c|c|c|}
\hline PT. PRPP & \multicolumn{2}{|c|}{ Nilai Efisiensi 0,3522} & \multirow[t]{2}{*}{ Potential Improvement } \\
\hline Variabel Input/ Output & Aktual & Target & \\
\hline Total Biaya & 8091.00 & 2849.52 & $-64.78 \%$ \\
\hline Modal disetor & 29520.00 & 10396.48 & $-64.78 \%$ \\
\hline Jumlah Tenaga Kerja & 45.00 & 15.85 & $-64.78 \%$ \\
\hline Variabel Input/ Output & Aktual & Target & Potential Improvement \\
\hline Pendapatan & 8704.00 & 8704.00 & $00.00 \%$ \\
\hline Laba Sebelum Pajak & 613.00 & 4020.81 & $555.92 \%$ \\
\hline Realisasi Deviden & 10.00 & 2536.80 & $25268.04 \%$ \\
\hline
\end{tabular}

Sumber: Hasil riset, 2017

Berdasarkan tabel-5, pada tahun 2016 jenis BUMD pada PT.PRPP mencapai nilai efisiensi yang sangat rendah di bawah $100 \%$, atau dapat dinyatakan inefisiensi. Capain tingkat efisiensi BUMD pada PT.PRPP hanya sebesar 0,3522 $(35,22 \%)$ atau masih kurang sebesar $-0,6478$ $(64,78 \%)$, untuk dapat mencapai nilai efisiensi 1 atau $100 \%$. Dengan demikan dapat diartikan bahwa jenis BUMD pada PT. PRPP di tahun 2016 tidak mampu menjalankan usaha secara efisien. Dengan kata lain, telah terdapat pengkombinasian besaran nilai faktor input yang kurang sesuai, (tidak optimal), sehingga diperoleh output yang tidak maksimal atau target output tidak dapat tercapai. Berdasarkan hasil riset pada tabel 5 dapat dilihat bahwa hasil analisis efisiensi teknis dengan pendekatan model DEA, maka dapat diketahui faktor yang menyebabkan ine- fisiensi BUMD pada PT.PRPP di tahun 2016 sebagai berikut:

a) Nilai aktual faktor input total biaya yang lebih besar dari target (aktual total biaya $\geq$ target total biaya) sebesar $64,78 \%$

b) Nilai aktual faktor input modal disetor lebih besar dari nilai target modal disetor (aktual modal disetor $\geq$ target modal disetor) sebesar $64.78 \%$

c) Nilai aktual jumlah tenaga kerja lebih besar dari nilai target jumlah tenaga kerja (aktual jumlah tenaga kerja $\geq$ target jumlah tenaga kerja) sebesar $64.78 \%$

d) Nilai aktual laba sebelum pajak kurang dari target laba sebelum pajak (aktual laba sebelum pajak $\leq$ target laba sebelum pajak) sebesar $-555.92 \%$ 
e) Nilai aktual realisasi deviden kurang dari nilai target realisasi deviden (aktual realisasi deviden $\leq$ nilai target realisasi deviden) sebesar $-25268.04 \%$.

Sesuai dengan tabel-5, maka dapat diketahui bahwa faktor penyebab terjadinya inefisiensi PT.PRPP pada tahun 2016 adalah besaran nilai faktor input dan output yang tidak sesuai antara nilai aktual dan nilai target. Sesuai dengan hasil analisis dengan teknik DEA, maka solusi yang harus dilakukan agar supaya BUMD jenis PT.PRPP mampu mencapai nilai efisiensi teknik sama dengan 1 atau 100\% pada tahun 2016 harus dapat dilakukan beberapa hal berikut:

a) Total biaya PT.PRPP tahun 2016 disarankan untuk diturunkan sebesar $-64.78 \%$ atau sebesar 5241,4,8 (juta rupiah), dari total biaya semula 8091 (juta rupiah) menjadi 2849,44 (juta rupiah).

b) Total modal yang disetorkan pemerintah daerah provinsi Jawa Tengah kepada PT.PRPP pada tahun 2016, disarankan dikurangi atau diturunkan sebesar $64.78 \%$ atau sebesar 19123,52 (juta rupiah). Besaran modal disetor yang semula 29520 (juta rupiah) menjadi 10396.48 (juta rupiah).

c) Jumlah tenaga kerja PT.PRPP tahun 2016 sebanyak 45 orang adalah tidak optimal, disarankan untuk dapat ditingkatkan kapasitasnya atau tingkatkan produktivitasnya, jika tidak maka terpaksa harus dikurangi (PHK) sebanyak 64.81\% atau dikurangi sebanyak 29 orang. Jumlah tenaga kerja semula 45 orang menjadi 16 orang.

d) Besaran laba sebelum pajak pada tahun 2016 hanya sebesar 613 (juta rupiah), maka disarankan untuk dapat dinaikan sebesar 555.92\% atau sebesar 3407.81 (juta rupiah). Dengan demikian, besaran laba sebelumnya 613 (juta rupiah) akan menjadi sebesar 4020.81 (juta rupiah). e) Realisasi deviden yang didapatkan oleh PT.PRPP pada tahun 2016 juga sangat kecil dan jauh dari target, sehingga harus dapat ditingkatkan sebesar $25268.04 \%$ atau ditingkatkan sebesar 2526.80 (juta rupiah). Artinya, besaran realisasi deviden pada 2016 yang semula hanya sebesar 10 juta rupiah harus menjadi 2536.80 juta rupiah.

\section{SIMPULAN}

Secara umum BUMD bidang jasa produksi di Propinsi Jawa Tengah selama periode riset 2011-2016, masih dapat dinyatakan efisien dengan tingkat rata-rata efisiensi teknis sebesar $88,50 \%$, dan capaian rerata tingkat efisiensi teknis tertinggi terjadi pada tahun 2014 yakni mencapai 93\% atau hanya 1 jenis BUMD saja yang tidak efisien. Selama periode riset tersebut terdapat 3 jenis dari 5 BUMD yang mampu mencapai tingkat efisien $100 \%$, dan ada 2 jenis BUMD yang tidak mampu mencapai efisien 100\%. Sedangkan, selama 6 tahun periode riset tersebut ada satu jenis BUMD yakni PT. PRPP yang tidak pernah mampu melakukan efisiensi teknis. Selain itu, hal yang harus diperhatikan dan diwaspadai adalah adanya kencenderungan tingkat efisiensi yang semakin menrurun selama periode riset tersebut khususnya pada periode akhir riset tahun 20142016.

Tingkat inefisiensi terendah kurang dari $50 \%$ terjadi pada BUMD jenis PT.PRPP yakni hanya mencapai 33,19\% di tahun 2015 dan $35,22 \%$ pada tahun 2016. Dengan demikian, tingkat inefisiensi PT.PRPP pada tahun 2015-2016 tersebuit dapat dinyatakan sangat tidak efisien dalam menjalankan bidang usahanya. Faktor penyebab inefisiensi BUMD bidang jasa produksi terjadi karena adanya kombinasi besaran faktor input (modal disetor, biaya total dan jumlah tenaga kerja) yang belum optimal (belum sesui) dalam upaya menghasilkan tingkat output tertentu yang maksimal. Solusi untuk 
meningkatkan tingkat efisiensi BUMD bidang jasa produksi yang belum mancapai $100 \%$, adalah harus dilakukan penyesuai besaran nilai input dengan besaran nilai output, sehingga mampu mencapai nilai efisiensi 100\%. Dengan kata lain, dapat dengan mengurangi besaran kombinasi nilai input (modal disetor, biaya total dan jumlah tenaga kerja) atau menambah besaran kombinasi nilai output (pendapatan, laba sebelum pajak dan realisasi deviden) sesuai dengan potensial improvement pada masing -masing faktor input dan output BUMD yang belum mencapai efisiensi 100\% tersebut, yakni PD.ABTU dan PT.PRPP.

\section{DAFTAR PUSTAKA}

Akbar dan Isa. (2012). Pengukuran Efisiensi BUMD: Studi Empirik PDAM Di Eks- Karisidenan Surakarta. BENEFIT Jurnal Management dan Bisnis, Vol. 16. No. 1. Hal: 6978. Juni 2012 Surakarta: Universitas Muhamadiyah Surakarta.

Alviya. (2011). Efisiensi dan Produktifitas Industri Kayu Olahan Indonesia Periode 20042007, Dengan Pendekatan Non Parametrik Data Envelopment Analysis. Jurnal Penelitian Sosial dan Ekonomi Kehutanan. Vol. 8. No. 2. Hal. 122-138. Bogor: Institut Pertanian Bogor.

Al-Delami, Khalid-Shahooth, dkk. (2006). Using Data Envelopment Analysis to Measure Cost Efisiency With An Aplication On Islamic Bank. Scientific Journal of Administrative Development. Vol. 41.

Ederer, Nikolaus. (2015). Evaluating Capital and Operating Cost Efficiency of Offshore Wind Farms. ELSEVIER. Vol. 42. Austria: Vienna University Tecnology.

Guerrini and Giulia. (2011). Measuring and comparing the efficiency of water utility companies A data envelopment analysis. ELSAVIER. Vol. 19. Hal. 202-209 Italy: University of Pisa.
Indratwati. (2009). Efisiensi Teknis BUMD, Dengan Metode DEA (Data Envelopment Aanalysis) (Studi PD.BKK Karanganyar 2006-2008). Skripsi Fakultas Ekonomi Universitas Sebelas Maret.

Johnes, dkk. (2011). Cost and Efficiency of Higher Education Institutions in England: A DEA Analysis. Journal of the Operational Research Society. 62. pp. 1282-197. ISSN. 2011.

Or Ilhan and Sarica. (2005). Efficiency Assessment of Turkish Power Plants Using Data Envelopment Analysis. ELSAVIER. Vol. 32. Turkey: University of Istanbul

Prasetyo, P. Eko. (2016). Fundamental Makro Ekonomi. Edisi 1, cetakan ke enam. Yogyakarta: Beta Offset.

P. Eko. (2010). Ekonomi Industri. Yogyakarta: Beta Offset.

P. Eko. (2017). Productivity of Textile Industry and Textile Products In Central Java. Jurnal Ekonomi dan Kebijakan. Vol.10. Edisi 2. Hal. 257-272 Semarang: Universitas Negeri Semarang.

Prasetyo, Danang. (2010). Analysis Efisiensi Teknis dan Alokatif Hotel Di Kawasan Wisata Tawangmangu Kabupaten Karanganyar Dengan Menggunakan Metode DEA. Skripsi. Surakarta: Fakultas Ekonomi UNS.

Undang-Undang No.23 Tahun 2014. Tentang Pemerintah Daerah.

Wijayanto A, Sutarno. (2010). Kinerja Efisiensi Fungsi Intermediasi Ban Persero Di Indonesia Dengan Menggunakan Pendekatan DEA. Jurnal Keuangan dan Perbankan. Vol.14. No.1. Hal. 110-112. 